\title{
Photovoltaic thermal (PVT) air collector with monofacial and bifacial solar cells: a review
}

\author{
Ahmad Fudholi ${ }^{1}$, Muslizainun Mustapha ${ }^{2}$, Ivan Taslim $^{3}$, Fitrotun Aliyah ${ }^{4}$, Arthur Gani Koto ${ }^{5}$, \\ Kamaruzzaman Sopian ${ }^{6}$ \\ 1,2,6 Solar Energy Research Institute, Universiti Kebangsaan Malaysia, 43600 Bangi Selangor, Malaysia \\ ${ }^{3,5}$ Universitas Muhammadiyah Gorontalo, Indonesia \\ ${ }^{4}$ Department of Nuclear Engineering and Engineering Physics, Universitas Gadjah Mada, Yogyakarta, Indonesia
}

\begin{abstract}
Article Info
Article history:

Received Nov 19, 2018

Revised Mar 1, 2019

Accepted Apr 8, 2019

Keywords:

Energy efficiency

Exergy efficiency

Renewable energy

Solar collector

ABSTRACT

Photovoltaic thermal (PVT) collectors directly convert solar radiation into electrical and thermal energy. A PVT collector combines the functions of a PV panel and a flat plate solar collector. The development of PVT air collectors is a very promising research area. At present, PVT air collectors are used in solar drying and solar air heaters. On the basis of existing literature, most PVT air collectors were built by using monofacial PV modules. The bifacial PV modules had two active surfaces that could capture solar radiation with its front and rear surfaces. Additional sunlight absorption through both surfaces resulted in an enhanced electrical power generation compared with the conventional monofacial PV. Therefore, bifacial PVT was considered to be useful and attractive due to its potential of enhancing overall system performances, including energy and exergy efficiencies. Findings of this review indicated that PVT air collector with bifacial solar cell produced a larger amount of electrical energy, which was approximately $40 \%$ higher than a monofacial PVT. The energy and exergy efficiencies of PVT air collector with monofacial solar cells range from $27 \%$ to $94 \%$ and from $4 \%$ to $18 \%$, respectively. For bifacial PVT, the energy and exergy efficiencies of PVT air collector range from $28 \%$ to $67 \%$ and from $8.2 \%$ to $8.4 \%$, respectively.
\end{abstract}

Copyright (C) 2019 Institute of Advanced Engineering and Science. All rights reserved.

\section{Corresponding Author:}

Ivan Taslim,

Universitas Muhammadiyah Gorontalo, Indonesia.

Email: ivantaslim@umgo.ac.id

\section{INTRODUCTION}

The utilisation of main energy resources by humanity relies on fossil fuels, such as natural gas, oil, nuclear energy and coal. However, the present stocks of fossil fuels are finite and not environmentally friendly. Fossil fuels emit many pollutants and cause serious environmental issues, such as global warming due to greenhouse gas emissions. Thus, renewable energy resources, which fulfil the criteria of green energy, are needed for world development and to meet the increasing demand for energy worldwide. Solar energy, which is the main source of conventional and renewable energy, has great potential and vast application prospects that can be used to meet majority of the total energy demand. The most promising, emerging solar energy technology is photovoltaic (PV) technology, which can transform solar radiation into electric energy through PV panels. From the PV panels, electrical and thermal energy can be produced simultaneously through the conversion of sunlight in the photovoltaic thermal (PVT) solar system [1-8].

Particularly, the development of solar collectors consists of evacuated tube, flat plate and concentrating solar collectors. Depending on specific requirements and technology used, solar collectors and PV systems are highly suitable alternatives for onsite renewable energy generation. They can also be used not only to transfer electricity but also for drying, space cooling and heating for terrestrial applications. Various 
studies have been conducted on PVT systems based on water and air because heat carriers have been developed and reviewed [9-13].

The overall performance of the PVT system can be evaluated based on the thermodynamic, environmental and economic impacts analysis.. In India, Tripathi et al. [14] states with regard to the energy loss factor during the transmission and distribution process in the supply energy, estimated $\mathrm{CO} 2$ emission rate per $\mathrm{kWh}$ is $2.08 \mathrm{~kg}$. They conducted studies on energy, energy and carbon analysis on solar collector PVT systems that were in a shielded part connected in series. The study was conducted by placing solar collectors on four conditions with different solar collector protection rates of $25 \%, 50 \%, 75 \%$ and $100 \%$. In addition, environmental-economic-exergy-energy analyses for different PVT air collector systems were studied [15-17]. Several types of PVT air collectors have been designed, evaluated and developed in various countries, thereby yielding varying degrees of technical performances based on energy-exergy analyses. In this review, we focused on energy and exergy efficiency of the PVT air collector with monofacial and bifacial solar cells.

\section{MONOFACIAL AND BIFACIAL PV}

A PV system converts sunlight into electrical current through a PV cell. The process by which the PV cell converts sunlight into electrical current is called the photoelectric effect. Sunlight consists of photons, and billions of which continuously hit the earth every second. These photons contain large quantities of energy corresponding to different wavelengths of the solar spectrum. When photons strike a PV cell, they are either reflected, absorbed or passed through. Electricity is generated by the absorbed photons. Photons with energy greater than the band-gap energy of the semiconductor create electron-hole pairs proportional to the incident irradiation when absorbed. The energy of the absorbed photon is absorbed by an electron in an atom of the semiconducting material of the PV cell. With the additional energy, the electron can escape from its normal position (valence band) in the atom to become free by jumping to the conducting band, leaving a hole behind. The electrical circuit is completed by the flow of these electrons and holes by using electrodes. Millions of electrons gain energy and become free to move along the conducting wires as millions of photons hit the PV cell. Solar cells and modules consist of thin conducting wires and a built-in electric field to provide voltage needed to move current through an external load. A small quantity of current produced at each cell can be significantly increased by connecting several cells together and keeping them free [18].

In conventional monofacial PV, the front surface is transparent with glass lamination to absorb solar radiation and convert it into electrical energy. The back surface, however, is opaque. The basic configuration of the monofacial PV is a metallic grid pattern on the front surface and a blank metal film on the rear surface of the solar cell. In contrast to monofacial PV, a bifacial PV has identical metallic grids on the front and back surfaces. Therefore, it can simultaneously absorb sunlight from the front and back surfaces. Figure 1 illustrates the cross-sections of the monofacial and bifacial PV and a comparison of the mechanism of solar radiation absorption between monofacial and bifacial PV.

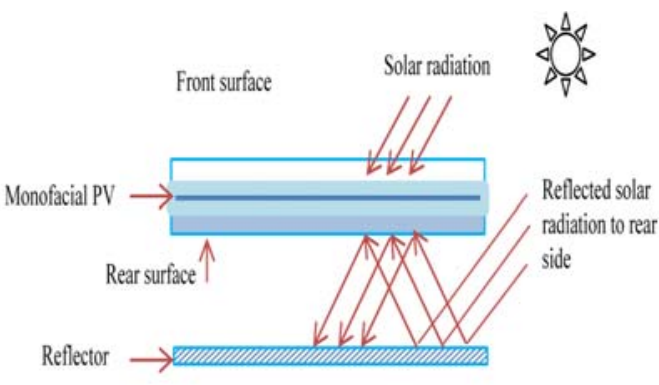

(a) Monofacial PV

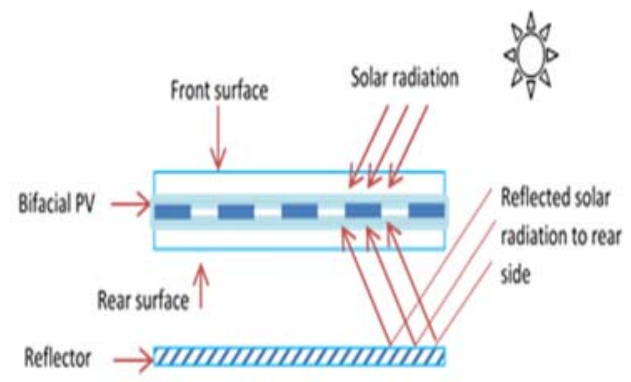

(b) Bifacial PV

Figure 1. Mechanism of solar radiation absorptions of monofacial and bifacial PV

Additional electrical energy generated by the bifacial PV panel is approximately $30 \%-90 \%$ higher compared with the monofacial PV panel $[19,20]$. Hubner et al. [21] reported that bifacial PV generated more electricity due to solar radiation absorption by the back surface compared with monofacial PV. Yang et al. [22] found that industrialised bifacial PV had front and rear efficiencies of $16.6 \%$ and $12.8 \%$, respectively. Electrical energy produced by the rear surface of bifacial PV strongly depended on the types of reflector,

Int J Pow Elec \& Dri Syst Vol. 10, No. 4, Dec 2019 : 2021 - 2028 
such as diffuse, mirror and semi-mirror. Lim et al. [23] reported that the total energy generated by the bifacial PV with a plane mirror underneath the panel was approximately $38.1 \%$ higher than the PV panel covered by a black plywood at the bottom. A study on the reflection performance of painted diffuse reflectors placed underneath bifacial PV conducted by Moehlecke et al. [20] determined that white-coloured reflectors had higher average reflectance at $75 \%$ compared with other colours, such as yellow, red, green, blue, brown and grey, which provided only $61 \%-32 \%$ reflection.

\section{EFFICIENCY OF BIFACIAL PV PANEL}

The total electrical energy efficiency of the bifacial PV panel strongly depends on the efficiency of the front and rear surfaces of the panel, efficiency of the reflector placed underneath the PV panel and the packing factor of the bifacial panel. Therefore, the total efficiency of bifacial PV panel can be expressed as

$$
\eta_{\text {panel }}=\eta_{\text {pv front }} \tau_{\text {glass }} P+\eta_{\text {pv } \text { rear }} \tau_{\text {glass }} \eta_{\text {reflector }} P
$$

where $\eta_{p v_{\text {front }}}$ and $\eta_{p v_{\text {rear }}}$ are the efficiencies of the front and rear surfaces of the bifacial PV panel, respectively; $\tau_{\text {glass }}$ is the transmittance of the panel glazing; $\eta_{\text {reflector }}$ is the reflection performance of the reflector; and $P$ is the packing factor of the panel.

The packing factor of a PV panel is defined as the ratio of effective absorber area of solar cells over the total area of the panel facing solar radiation, which is expressed as follows:

$$
\text { Packing factor, } P=\frac{\text { area of } P V \text { cells in panel }}{\text { actual area of a panel }} \text {. }
$$

For example, if a panel contains six cells (Figure 2), then the packing factor of the panel can be calculated as the total area of the six cells $(6 \times a \times b)$ divided by the total area of the panel $(L \times W)$.

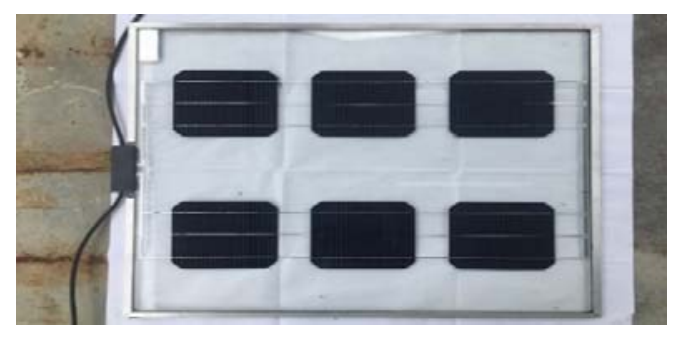

(a)

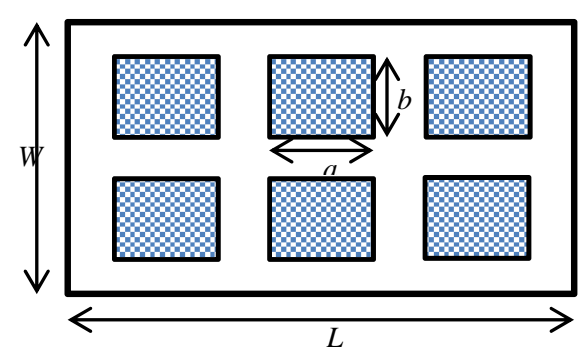

(b)

Figure 2. A six-cell bifacial PV panel, (a) photograph, (b) schematic.

\section{PVT AIR COLLECTOR WITH MONOFACIAL SOLAR CELL}

In this section, studies on PVT air collectors are reviewed. Various types of PVT air collectors have been designed and evaluated theoretically and experimentally. These collectors are generally classified according to the air flow pattern, that is, whether air flows above the absorber, below the absorber, on both sides of the absorber, in single and in double pass. Figures 3 shows photograph of PVT air collectors with monofacial PV panel, which PV panel is monocristaline type solar cell.

Agrawal and Tiwari [24] conducted a theoretical and experimental study of PVT air collector and reported PV and thermal efficiencies of $7.13 \%$ and $33.54 \%$, respectively. Sarhaddi et al. [25] conducted energy and exergy analyses of PVT air collector and reported PV, thermal and PVT efficiencies of 10\%, $17.18 \%$ and $45 \%$, respectively; the PVT exergy efficiency was $10.75 \%$. Agrawal and Tiwari [26] performed energy and exergy analyses of PVT air collector under cold climatic conditions and reported PVT energy efficiency of 53.7\%. Sarhaddi et al. [27] also performed a detailed energy and exergy analyses of a PVT air collector to calculate thermal and electrical parameters, exergy components and exergy efficiency of a typical PVT air collector. This analysis showed that increasing the inlet air velocity or solar radiation intensity initially increased the exergy efficiency and then decreased it after reaching the peak maximum inlet air velocity or solar radiation intensity. Moreover, increasing the wind speed increased the exergy efficiency. This study also reported that the working fluid significantly affected the exergy efficiency, and the exergy

Photovoltaic thermal (PVT) air collector with monofacial and bifacial solar cells: a review (Ahmad Fudholi) 
efficiency increased when an incompressible fluid (water) was used in the PVT collector system. Amori and Al-Najjar [28] theoretically studied the thermal and electrical performances of PVT air collector in Iraq. They reported PV, thermal and PVT efficiencies of 9\%-12.3\%, 19.4\%-22.8\% and $47.8 \%-53.6 \%$, respectively. Agrawal et al. [29] performed a theoretical and experimental study of PVT air collectors connected in series and reported PV and thermal efficiencies of $12.4 \%$ and $35.7 \%$ respectively. Rajoria et al. [30] theoretically and experimentally studied PVT air collector and reported PVT energy and exergy efficiencies of $11.3 \%$ and $16.3 \%$, respectively. Amori and Abd-AlRaheem [31] studied various PVT air collectors and reported PV and thermal efficiencies of $8.3 \%-10.4 \%$ and $46 \%-62 \%$, respectively. Good et al. [32] reported PV and thermal efficiencies of $17.4 \%$ and $71.5 \%$, respectively. Ahn et al. [33] reported PV, thermal and PVT efficiencies of $15 \%, 23 \%$ and $38 \%$, respectively. Rajoria et al. [34] reported PV and thermal efficiencies of 3.1\%-9.1\% and $12.1 \%-28.1 \%$ respectively. Li et al. [35] performed a theoretical and experimental research of PVT air collector in the hot summer and cold winter zones. They reported PV, thermal and PVT efficiencies of $11.9 \%-12.4 \%, 50 \%$ and $77.7 \%$, respectively. Gholampour and Ameri [36] conducted energy and exergy analyses of PVT flat transpired collectors through theoretical and experimental studies. They reported PVT exergy efficiency was $8.66 \%$; based on energy analysis, the thermal and PVT efficiencies were $69.9 \%$ and $55 \%$, respectively. Slimani et al. [37] theoretically and experimentally analysed PVT air collector for an indirect solar dryer. They reported PV, thermal and PVT efficiencies of $10.5 \%, 70 \%$ and $90 \%$, respectively. Hazami et al. [38] conducted a theoretical and experimental study of PVT air collectors through energy and exergy analyses. They reported a PVT exergy efficiency of $14.8 \%$. Based on energy analysis, the PV and thermal efficiencies were $15 \%$ and $50 \%$, respectively. Recently, Fudholi et al. [44] theoretically and experimentally investigated PVT air collector with $\nabla$-groove. The exergy and energy efficiencies of the PVT were $12.66 \%-12.91 \%$ and $31.21 \%-94.24 \%$, respectively. The thermal and PV efficiencies were $21.3-\%-$ $82.9 \%$ and $9.87 \%-11.34 \%$, respectively. In addition, Fudholi et al. [46] also experimentally and theoretically studied PVT air collector with v-groove using energy-exergy analyses. They concluded that the PVT exergy efficiency of the PVT air collector with a v-groove ranged from $12.81 \%$ to $14.41 \%$ and 12.09 to $13.40 \%$ with an average of $13.36 \% 12.89$ for the theoretical and experimental study, respectively.

As summarize, several studies on the energy and exergy analyses on PVT air collectors in 2010 2019 are listed in Table 1.

Table 1. Studies conducted on PVT air collectors in 2010-2019

\begin{tabular}{|c|c|c|c|c|c|c|}
\hline \multirow[t]{2}{*}{ Ref. } & \multirow[t]{2}{*}{ Year } & \multirow[t]{2}{*}{ Study } & \multicolumn{3}{|c|}{ Energy efficiency (\%) } & \multirow{2}{*}{$\begin{array}{l}\text { PVT } \\
\text { Exergy } \\
\text { efficiency }\end{array}$} \\
\hline & & & PV & Thermal & PVT & \\
\hline [24] & 2010 & Experimental & NA & NA & 53.7 & NA \\
\hline [25] & 2010 & Theoretical and experimental & 7.13 & 33.54 & NA & NA \\
\hline [26] & 2010 & Theoretical and experimental & 10 & 17.18 & 45 & NA \\
\hline [27] & 2010 & Experimental & 10 & 17.18 & 45 & 10.75 \\
\hline [28] & 2012 & Theoretical & $9-12.3$ & $19.4-22.8$ & $47.8-53.6$ & NA \\
\hline [29] & 2012 & Theoretical and experimental & 12.4 & 35.7 & NA & NA \\
\hline [30] & 2013 & Theoretical and experimental & NA & NA & NA & 16.3 \\
\hline [31] & 2014 & Experimental & $8.3-10.4$ & $46-62$ & NA & NA \\
\hline [32] & 2015 & Theoretical and experimental & $11.9-12.4$ & 50 & 77.7 & NA \\
\hline [33] & 2015 & Experimental & 17.4 & 71.5 & NA & NA \\
\hline [34] & 2015 & Experimental & 15 & 23 & 38 & NA \\
\hline [35] & 2015 & Experimental & $3.1-9.1$ & $12.1-28.1$ & NA & NA \\
\hline [36] & 2016 & Theoretical and experimental & 10.5 & 70 & 90 & NA \\
\hline [37] & 2016 & Theoretical and experimental & NA & 69.91 & 55 & 8.66 \\
\hline [38] & 2016 & Theoretical and experimental & 15 & 50 & NA & 14.8 \\
\hline [39] & & Theoretical and experimental & 13.8 & 56.2 & NA & NA \\
\hline [40] & 2016 & Theoretical and experimental & 10 & $22-78$ & NA & NA \\
\hline [41] & 2016 & Experimental & 13.2 & 62 & NA & NA \\
\hline [42] & 2016 & Theoretical and experimental & NA & NA & 68.5 & NA \\
\hline [43] & 2018 & Experimental & $13.5-14.6$ & & $72-83$ & $16.4-16.6$ \\
\hline [44] & 2018 & Theoretical and experimental & $9.87-11.34$ & $21.3-82.9$ & $31.21-94.24$ & $12.66-12.91$ \\
\hline [45] & 2019 & Theoretical & $7-15$ & $5-20$ & $35-56$ & NA \\
\hline [46] & 2019 & Theoretical and experimental & NA & NA & NA & $12.09-14.41$ \\
\hline
\end{tabular}

From Table 1, the energy and exergy efficiencies of PVT air collector range from $31 \%$ to $94 \%$ and from $7 \%$ to $18 \%$, respectively. The efficiencies vary because of differences in the heat transfer area through the absorber (finned absorber and corrugated surfaces), design and air flow configuration (single-pass and double-pass; with and without glass cover).

Int J Pow Elec \& Dri Syst Vol. 10, No. 4, Dec 2019 : 2021 - 2028 


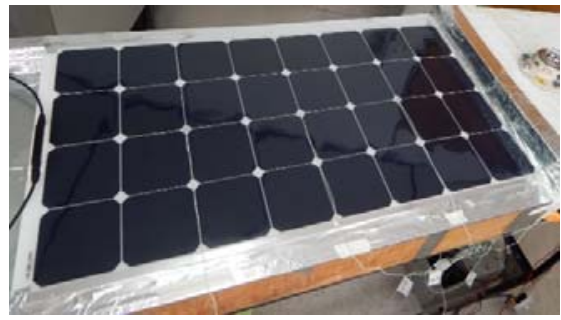

(a)

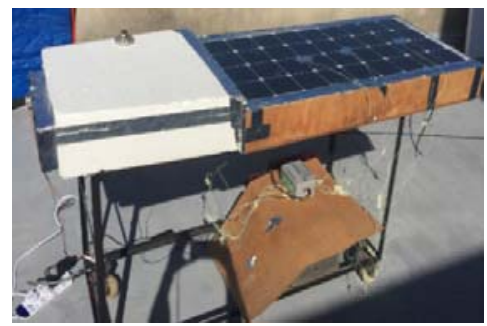

(b)

Figure 3. A PVT air collector with monofacial PV panel, (a) with flexible PV panel, (b) with non-flexible PV panel.

\section{PVT AIR COLLECTOR WITH BIFACIAL SOLAR CELL}

Figures 4 shows photograph of PVT air collectors with different cell bifacial. Ooshaksaraei et al. [47] developed four new designs of PVT air collectors with bifacial solar cells. Model I is a single-path PVT collector with air stream flows between the PV lamination and reflector. Model II has two parallel air stream flows above and beneath the PV lamination. Model III is a double-path PVT collector with the second air stream flowing in the opposite direction compared with the first air stream. In Model IV, the air flows between the glazing and the PV lamination and returns back to the second channel. They concluded that model II had the highest total energy efficiency (51\%-67\%), followed by model III (47\%-62\%), model IV (42\%-56\%), and model I (28\%-49\%). However, collector model I showed the highest exergy efficiency $(8.2 \%-8.4 \%)$.

The most significant advantage of the PVT collector integrated with bifacial PV panel is the enhancement of electrical energy production because of the increase in solar absorption from the rear surface. This improvement can be realised by providing a top glass cover over bifacial PV panels, placing a reflector beneath the panels and ensuring that air stream flows through one or both channels, as shown in the new designs of bifacial PVT air collector. In addition, the mathematical model of air-based bifacial PVT is developed with the following considerations: the convection heat transfer inside the collector is forced heat transfer, and the temperatures at the front and rear sides of the bifacial PV panel are assumed to be the same. The energy balance model allows the calculation of the electrical output and the outlet air temperature to obtain the efficiency of the collector. A detailed analysis of the energy balance of different collector designs is required to compare the thermal and electrical performances of the systems. Ooshaksaraei et al. [48] indicated that the bifacial PVT air collector with a semi-mirror reflector presented a higher total power output compared with a collector using a diffuse reflector. Sopian et al. [49] studied performance characterization of single-path and double-path air-based bifacial photovoltaic thermal solar collector as shown in Figure 5 and 6. They reported temperature profile and PVT efficiency of bifacial PVT collector base on simulation study as shown in Figure 7 and 8, respectively.

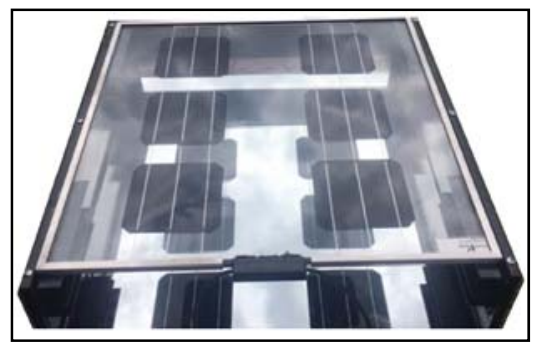

(a)

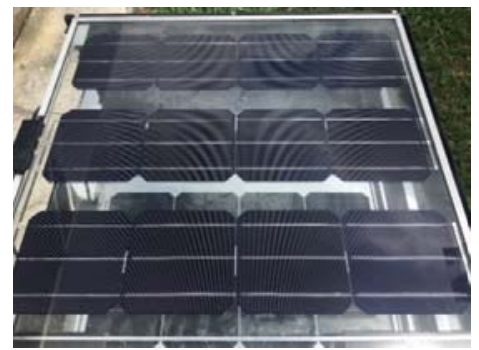

(b)

Figure 4. A PVT air collector with bifacial PV panel, (a) six-cell bifacial PV panel, (b) twelve-cell bifacial PV panel.

Photovoltaic thermal (PVT) air collector with monofacial and bifacial solar cells: a review (Ahmad Fudholi) 


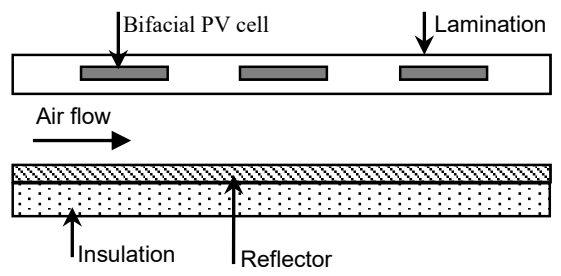

(a)

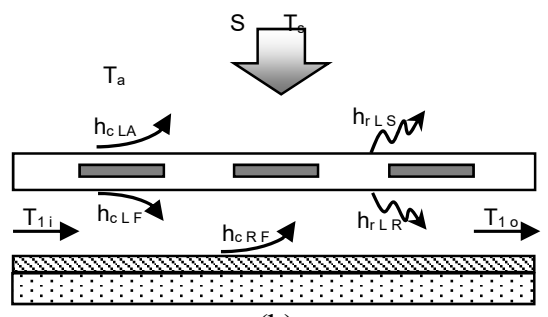

(b)

Figure 5. Model 1: Single path bifacial PVT collector. (a) Cross section view, (b) heat transfer coefficient of energy balance model

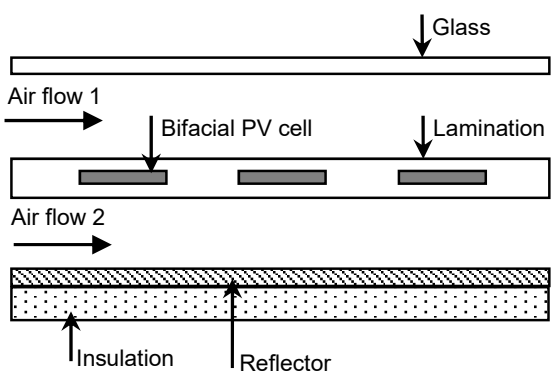

(a)

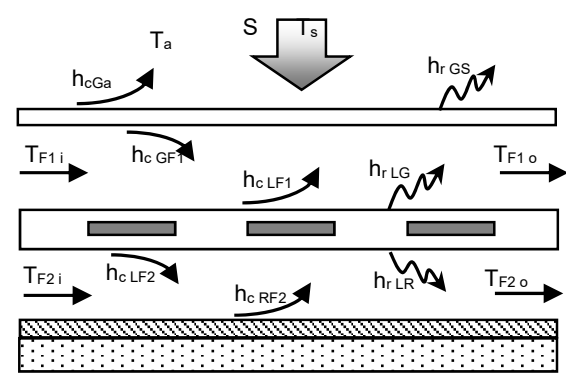

(b)

Figure 6. Model 2: Double path parallel flow panel. (a) Cross section view, (b) heat transfer coefficient of energy balance model.

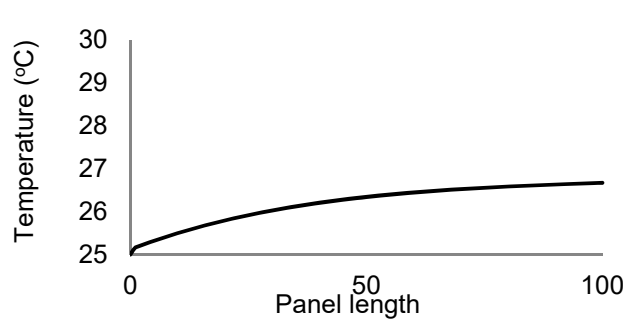

(a)

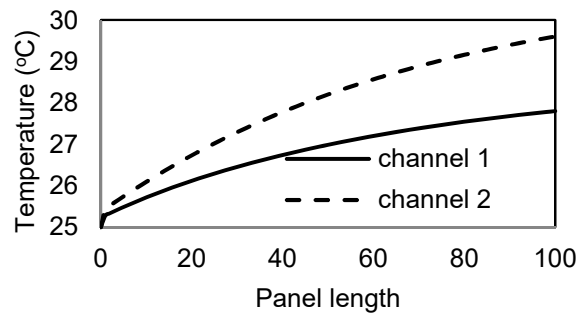

(b)

Figure 7. Air flow along panel length for (a) single path (b) double path parallel stream .

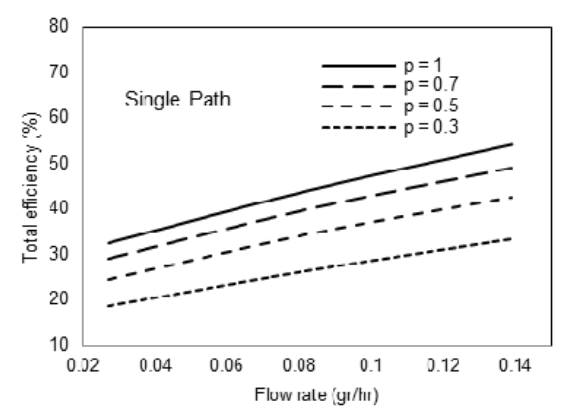

(a)

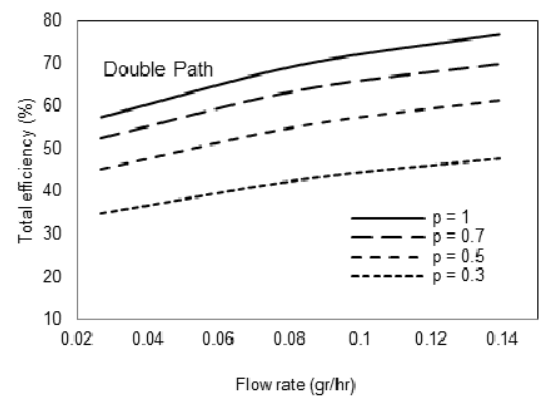

(b)

Figure 8. PVT efficiency of two models at different packing factor, (a) single path, (b) double path. 


\section{CONCLUSIONS}

The review for PVT air collectors with monofacial and bifacial solar cells were presented. This review presents the following conclusions:

(i) The PVT air collector integrated with a bifacial bifacial solar cell generates a larger amount of electricity (approximately 40\%) than a monofacial PVT without considerable increase in cost [50]. Moving forward, different types of PV cells, such as perovskite, organic and dye-sensitised solar cells, may be used to increase PV efficiency rather than using monocrystalline silicon-type PV cells, as presented in previous studies. Furthermore, other types of reflectors can be used as alternatives, such as parabolic and spherical reflectors, instead of using mirror or semi-mirror. These suggestions provide useful information for further development of bifacial PVT air collectors to increase thermal and electrical efficiencies.

(ii) The energy and exergy efficiencies of PVT air collector with bifacial solar cells range from $28 \%$ to $67 \%$ and from $8.2 \%$ to $8.4 \%$, respectively.

(ii) The energy and exergy efficiencies of PVT air collectors with monofacial solar cells were $39 \%$ to $94 \%$ and $12.66 \%$ to $12.91 \%$, respectively.

\section{ACKNOWLEDGEMENTS}

We gratefully acknowledge the funding from USAID through the SHERA program-Centre for Development of Sustainable Region (CDSR). In year 2017-2021 CDSR is led by Center for Energy StudiesUGM.

\section{REFERENCES}

[1] N.S. Nazri, et al., "Energy economic analysis of photo-voltaic-thermal-thermoelectric (PVT-TE) air collectors," Renewable and Sustainable Energy Review, vol. 92, pp. 187-97, 2018.

[2] M. Mustapha, et al., "Review on energy and exergy analysis of air and water based photovoltaic thermal (PVT) collector, "International Journal of Power Electronics and Drive Systems (IJPEDS), 9 (3), pp. 1383-1389, 2018.

[3] N.S. Nazri et al., "Mathematical modeling of photovoltaic thermal-thermoelectric (PVT-TE) air collector. International Journal of Power Electronics and Drive Systems (IJPEDS), 9 (2), pp. 795-802, 2018.

[4] N.S. Nazri, "Experimental study of photovoltaic thermal-thermoelectric (PVT-TE) air collector," International Journal of Power Electronics and Drive Systems (IJPEDS), 9 (3), pp. 1406-1412, 2018.

[5] M. Zohri et al., "Photovoltaic thermal (PVT) system with and without fins collector: theoretical approach," International Journal of Power Electronics and Drive System (IJPEDS) 8(4), pp. 1756-63, 2017.

[6] M. Zohri, et al., "Exergy assessment of photovoltaic thermal with v-groove collector using theoretical study," TELKOMNIKA 16(2), pp. 550-57, 2018.

[7] A. Fudholi et al., "R\&D of Photovoltaic Thermal (PVT) Systems: an overview," International Journal of Power Electronics and Drive Systems (IJPEDS) 9 (2), pp. 803-10, 2018.

[8] A. Fudholi, et al., "Collector efficiency of the double-pass solar air collectors with fins," Proceedings of the 9th WSEAS International Conference on SYSTEM SCIENCE and SIMULATION in ENGINEERING (ICOSSSE'10), Japan, 2010, pp. 428-34.

[9] A. Fudholi, et al., "Experimental Study of the double-pass solar air collector with staggered fins," Proceedings of the 9th WSEAS International Conference on SYSTEM SCIENCE and SIMULATION in ENGINEERING (ICOSSSE'10), Japan, 2010, pp. 410-14.

[10] N.F.M. Razali et al., "Experiment study of water based photovoltaic-thermal (PV/T) collector," International Journal of Electrical and Computer Engineering (IJECE) 9(1), pp. 118-125, 2019.

[11] A. Ibrahim et al., "Efficiencies and improvement potential of building integrated photovoltaic thermal (BIPVT) system," Energy Conversion and Management, vol. 77, pp. 527-34, 2014.

[12] A. Fudholi, et al., "Review of solar photovoltaic/thermal (PV/T) air collector," International Journal of Electrical and Computer Engineering (IJECE) 9 (1), pp. 126-133, 2019.

[13] A. Fudholi, et al., (2019), „Energy and exergy analysis of air based photovoltaic thermal (PVT) collector: a review“. International Journal of Electrical and Computer Engineering (IJECE) 9 (1), 109-117.

[14] R. Tripathi, et al., "Overall energy, exergy and carbon credit analysis of N partially covered photovoltaic thermal (PVT) concentrating collector connected in series," Solar Energy, vol. 136, pp. 260-267, 2016.

[15] Shyam and G.N. Tiwari, "Analysis of series connected photovoltaic thermal air collectors partially covered by semitransparent photovoltaic module", Solar Energy, vol. 137, pp. 137:452-462, 2016.

[16] C.S. Rajoria, et al., "A Novel investigation of building integrated photovoltaic thermal (BiPVT) system: A comparative study. Solar Energy, vol. 131, pp. 107-118, 2016

[17] C.S. Rajoria, et al., "A newer approach on cash flow diagram to investigate the effect of energy payback time and earned carbon credits on life cycle cost of different photovoltaic thermal array systems", Solar Energy, vol. 124, pp. 124:254-267, 2016.

[18] J. Zhang, et al., "Enlarging photovoltaic effect: combination of classic photoelectric and ferroelectric photovoltaic effects,".Scientific Reports, vol. 3, pp. 1-6. doi:10.1038/srep02109, 2013.

[19] T. Joge, et al.,"Applications and field tests of bifacial solar modules". Proceedings of the 29th IEEE Photovoltaic Specialists Conference 2002;1549-1552.

Photovoltaic thermal (PVT) air collector with monofacial and bifacial solar cells: a review (Ahmad Fudholi) 
[20] A. Moehlecke, et al., "Photovoltaic module with colored diffuse reflectors". Proceedings of the European Photovoltaic Solar Energy Conference 2001;785-787.

[21] A. Hubner, et al.,"Temperature behavior of monofacial and bifacial silicon solar cells". Photovoltaic Specialists Conference 1997; 223-226.

[22] L. Yang, et al.,"High efficiency screen printed bifacial solar cells on monocrystalline CZ silicon. Progress in Photovoltaics: Research and Applications 2011;19(3):275-279.

[23] Y. S. Lim, et al.,"Faidz. Design and evaluation of passive concentrator and reflector systems for bifacial solar panel on a highly cloudy region - A case study in Malaysia", Renewable Energy, vol. 63, pp. 415-425, 2014.

[24] B. Agrawal \& G.N. Tiwari, "Life cycle cost assessment of building integrated photovoltaic thermal (BIPVT) systems,"Energy and Buildings, vol. 42, pp. 1472-81, 2010.

[25] F. Sarhaddi, et al., "An improved thermal and electrical model for a solar photovoltaic thermal (PV/T) air collector," Applied Energy, vol. 87, pp. 2328-39, 2010.

[26] B. Agrawal \& G.N. Tiwari,"Optimizing the energy and exergy of building integrated photovoltaic thermal (BIPVT) systems under cold climatic conditions,"Applied Energy, vol. 87, pp. 417-26, 2010.

[27] F. Sarhaddi, et al., "Exergetic performance assessment of a solar photovoltaic thermal (PV/T) air collector,"Energy and Buildings, vol. 42, pp. 2184-99, 2010.

[28] K.E. Amori, and H.M.T. Al-Najjar," Analysis of thermal and electrical performance of a hybrid (PV/T) air based solar collector for Iraq,"Applied Energy, vol. 98, pp. 384-95, 2012.

[29] S. Agrawal, et al., "Indoor experimental analysis of glazed hybrid photovoltaic thermal tiles air collector connected in series,"Energy and Buildings, vol. 53, pp. 145-51, 2012.

[30] C.S. Rajoria, et al., "Exergetic and enviroeconomic analysis of novel hybrid PVT array, "Solar Energy, vol. 88, pp. 110-19, 2013.

[31] K.E. Amori, M.A. Abd-AlRaheem, "Field study of various air based photovoltaic/thermal hybrid solar collectors,"Renewable Energy, vol. 63, pp. 402-14, 2014.

[32] C. Good, et al., "Solar energy for net zero energy buildings - A comparison between solar thermal, PV and photovoltaic-thermal (PV/T) systems,"Solar Energy, vol. 122, pp. 986-96, 2015.

[33] J.G. Ahn, et al., "A Study on Experimental Performance of Air-Type PV/T Collector with HRV,"Energy Procedia, vol. 78, pp. 3007-12, 2015.

[34] C.S. Rajoria, et al., "Exergetic and enviroeconomic analysis of semitransparent PVT array based on optimum air flow configuration and its comparative study,"Solar Energy, vol. 122, pp. 1138-45, 2015.

[35] Y. Li, et al., " Performance study of a solar photovoltaic air conditioner in the hot summer and cold winter zone,"Solar Energy, vol. 117, pp. 167-79, 2015.

[36] M. Gholampour \& M. Ameri,"Energy and exergy analyses of Photovoltaic/Thermal flat transpired collectors: Experimental and theoretical study,"Applied Energy, vol. 164, pp. 837-56, 2016.

[37] M.E.A.Slimani, et al., "Study and modeling of energy performance of a hybrid photovoltaic/thermal solar collector: Configuration suitable for an indirect solar dryer," Energy Conversion and Management, vol. 125, pp. 209-21, 2016.

[38] M. Hazami, et al., " Energetic and exergetic performances analysis of a PV/T (photovoltaic thermal) solar system tested and simulated under to Tunisian (North Africa) climatic conditions,"Energy, vol. 107, pp. 78-94, 2016.

[39] J.C. Mojumder, et al., "An experimental investigation on performance analysis of air type photovoltaic thermal collector system integrated with cooling fins design," Energy and Buildings, vol. 130:272-285, 2016.

[40] I. Tabet, et al., "An experimental investigation on performance analysis of air type photovoltaic thermal collector system integrated with cooling fins design," The European Physisical Journal Plus, vol. 131(41), pp. 1-15, 2016.

[41] M. Rosa-Clot, et al., "Experimental photovoltaic-thermal Power Plants based on TESPI panel," Solar Energy, vol. 133, pp. 305-314, 2016.

[42] S. Tiwari and G.N. Tiwari, "Exergoeconomic analysis of photovoltaic-thermal (PVT) mixed mode greenhouse solar dryer,” Energy, vol. 114, pp. 155-164, 2016.

[43] B. Das, et al.," "Performance analysis of single glazed solar PVT air collector in the climatic condition of NE India," Proceedings: $4^{\text {th }}$ International Electronic Confrence on Entropy and Its Application (ECEA 2017), pp. 114, 2018.

[44] A. Fudholi, et al., "Energy and exergy analyses of photovoltaic thermal collector with $\nabla$-groove," Solar Energy, vol. 159 , pp. 742-50, 2018.

[45] A.L. Abdullah, et al., "Numerical analysis of solar hybrid photovoltaic thermal air collector simulation by ANSYS," CFD Letter, vol. 11(2), pp. 1-11, 2019.

[46] A. Fudholi, et al., "Exergy and sustainability index of photovoltaic thermal (PVT) air collector: a theoretical and experimental study," Renewable and Sustainable Energy Reviews, vol. 100, pp. 44-51, 2019.

[47] P. Ooshaksaraei, et al.,"Performance of four air-based photovoltaic thermal collectors configurations with bifacial solar cells", Renewable Energy, vol. 102, pp. 279-293, 2017.

[48] P. Ooshaksaraei, et al.,"Characterization of a bifacial photovoltaic panel integrated with external diffuse and semimirror type reflectors". International Journal of Photoenergy 2013;7.

[49] K. Sopian, et al.,. "Performance characterization of single-path and double-path airbased bifacial photovoltaic thermal solar collector," Proc. of the WSEAS- Recent Advances in Energy, Environment and Geology 2013, pp. 42-47, 2013.

[50] B. Robles-Ocampo, et al.," Photovoltaic/thermal solar hybrid system with bifacial PV module and transparent plane collector", Solar Energy Materials \& Solar Cells, vol. 91, pp. 1966-1971, 2007.

Int J Pow Elec \& Dri Syst Vol. 10, No. 4, Dec 2019 : 2021 - 2028 